\title{
L'ensenyament del català com a llengua addicional basat en conceptes
}

\author{
Ernesto Martín Peris ${ }^{1}$ \\ Universitat Pompeu Fabra ${ }^{2}$ \\ ernesto.martin@upf.edu
}

Rebut: 15 de maig del 2020

Acceptat: 12 de setembre del 2020

\section{Resum}

La teoria sociocultural de l'aprenentatge ha estat aplicada a l'ensenyament de llengües addicionals des de fa unes dècades. Inspirada en la psicologia de Vigotski, potencia la dimensió social del desenvolupament de les capacitats i les activitats mentals de la persona, que es realitzen sempre en dues fases: una primera en la qual l'aprenent és capaç de dur-les a terme només en interacció amb una altra, i una segona en la qual pot actuar de forma autònoma. Proposa un model didàctic en el qual la interacció entre alumnes no es limita a la resolució pràctica de tasques comunicatives, sinó que té una autèntica funció de mediació de l'aprenentatge i de foment de processos cognitius. En el cas de l'ensenyament de continguts gramaticals, proposa que la unitat d'aprenentatge sigui un concepte i no una forma lingüística. L'acció del docent, també, es veu reforçada per un conjunt d'artefactes, el treball dels alumnes amb els quals, a partir de la seva percepció sensible, suposa una guia per l'aprenentatge. L'article explora l'aplicació d'un d'aquests artefactes a l'ensenyament dels pronoms febles en català.

\section{Paraules clau}

Aprenentatge basat en conceptes, lingüística cognitiva, llengües addicionals, mediació en l'aprenentatge, pronoms febles

\begin{abstract}
The Sociocultural Theory of Learning has been applied to the teaching of additional languages for some decades now. Inspired by Vygotsky's writings on Psychology, it boosts the social dimension in the development of the individual's abilities and mental activities, which always materialize in two phases. In the first one, the learner can accomplish a particular task while interacting with another person, and in the second, they are able to perform it independently. The above mentioned theory proposes a pedagogical model in which the interaction among learners does not only provide the means for the practical resolution of a communicative task, but it also plays an actual mediating role in the learning and cognitive processes. In the case of grammar teaching, the model suggests that the learning unit be a concept, and not a linguistic form. Moreover, the teacher's action is supported by an array of artifacts that are perceived visually and hence offer an enhanced help and guide to the learners in their mental learning activity. This article explores the implementation of one of such artifacts in the teaching of clitics in Catalan.
\end{abstract}

\section{Key words}

Concept based learning, additional languages, clítics, Cognitive Linguistics, mediated learning

1 He d'agrair a Carme Bach, companya del grup de recerca Gr@el (UPF), el seu valuós suport i assessorament lingüístic, imprescindibles per a la confecció d'aquest article.

2 Aquest article està vinculat al projecte de recerca ECODAL: Evaluación de la competencia discursiva de aprendices adultos plurilingües: detección de necesidades formativas y pautas para un aprendizaje autónomo (EDU2016-75874-P), del Plan Nacional de Investigación Científica, Desarrollo e Innovación Tecnológica 2016 del Ministerio de Economía, Industria y Competitividad, cofinançat per l'Agencia Estatal de Investigación i el Fondo Europeo de Desarrollo Regional i al grup GR@EL (Grup de recerca en aprenentatge i ensenyament de llengües) (AGAUR, 2017 SGR 195). 
"Aprendre una nova llengua [...] implica l'apropiació de nous coneixements conceptuals (i no tan sols instrumentals), o bé la modificació dels ja existents" (Lantolf \& Poehner).

\section{Introducció}

En la història de l'ensenyament de les llengües addicionals (endavant, LA) hi ha hagut enfocaments molt diversos, des que a les acaballes del s. XIX els lingüistes del Moviment de Reforma (Martín Peris 2008) van proposar una metodologia nova per a les llengües anomenades vives (o també, actualment, idiomes), enfront a les denominades llengües mortes o clàssiques (bàsicament, llatí i grec). Va ser així que nasqué una nova disciplina, la lingüística aplicada ("aplicada", en aquells moments, a l'ensenyament d'idiomes). El fruit més reeixit d'aquesta nova disciplina va ser el mètode directe, que feia èmfasi en la pràctica oral d'estructures gramaticals i vocabulari de la llengua addicional, i venia a substituir l'antic mètode de gramàtica-traducció, que consistia a llegir textos originals i traduir-los. L'evolució d'aquesta disciplina al llarg del segle XX es caracteritza per una successió de propostes "a la recerca del mètode perfecte", entès el concepte de mètode com un conjunt de tècniques i procediments vàlids per a qualsevol situació i context ${ }^{3}$. Succeeix sovint que el mètode adoptat no dona els resultats esperats, i aleshores es mira de reformar-lo o substituir-lo per un de nou, que posa l'èmfasi en uns aspectes diferents de l'aprenentatge, desatesos o ignorats pel mètode anterior. En aquest procés, l'atenció es centra en aspectes diversos; per exemple, a un mètode basat en uns principis psicològics de tipus conductista se n'hi contraposa un de base cognitiva. Aquesta dinàmica pendular entre mètodes es va aturar amb l'abandonament d'aquella recerca del mètode ideal: "There is no best method", titula Prabhu un article seu (1990), en el qual afirma que més important que els principis i les tècniques d'un mètode és la capacitat del docent per a adaptar-se a les condicions del seu context particular; i Kumaravadivelu $(1994,2006)$ escriu un llibre sobre la situació actual, que denomina Postmethod condition, en el qual proposa un seguit d'estratègies de l'actuació docent, més que no unes tècniques concretes com feien els mètodes històrics. A les darreres dècades del s. XX s'estén amb força l'enfocament comunicatiu (Martín Peris 2008, "Enfoque comunicativo"), una proposta revolucionària pel que fa a la fixació d'objectius del currículum i a la selecció i organització dels continguts dels programes, que explícitament renuncia a presentar-se com un nou mètode i adopta en lloc seu la categoria d'enfocament, és a dir, fa èmfasi en una teoria del que és parlar una llengua i una altra del que és aprendre'n una de nova, i deixa al criteri dels docents la forma concreta d'instrumentar en cada cas un ensenyament fonamentat en aquestes teories.

Un dels punts més importants de discrepància entre els diferents mètodes — si no el central— és la suposada contraposició "gramàtica-fluïdesa" o, si es vol, "correcció gramatical - eficàcia comunicativa". En uns casos es fa més èmfasi en les formes i estructures gramaticals, i en uns altres se'n fa més en la pràctica de la comunicació a l'aula. Aquest punt de discrepància afecta tres àrees: l'establiment dels objectius del currículum, la selecció i seqüenciació dels continguts del programa, i les pràctiques d'aprenentatge a l'aula (explicacions dels manuals i dels docents, exercicis i activitats dels aprenents, continguts i procediments dels exàmens...).

L'origen del debat es pot situar en la continuada observació que, en el progressiu domini de la nova llengua per part dels aprenents, apareix una mena de resistència a incorporar en el seu ús determinats trets de les formes gramaticals i, alhora, una persistència de determinats errors, aparentment refractaris a tota correcció. La conseqüència que alguns n'extreien era que calia dissenyar un programa orientat a la prevenció i correcció de l'error (que solia atribuir-se — posteriorment s'ha demostrat que erròniament en gran part dels casos - a una

3 Va haver-hi tota una bibliografia al voltant del concepte de mètode i els seus components. Per a una clarificació sobre la tripleta enfocament-mètode-tècnica és prou il.lustratiu Richards \& Rodgers (1986). 
interferència negativa de la L1 de l'alumne). Per tal d'assolir aquesta fita, era prioritari focalitzar el programa en les formes lingüístiques de la LA, triant-ne aquelles que contrastaven amb les de la L1; el domini de la fluïdesa es deixava a càrrec d'unes activitats complementàries de "conversa espontània". Contràriament, entre molts cercles de professionals de l'ensenyament de LA havia arrelat la idea que la gramàtica era irrellevant per a l'èxit en la comunicació. La correcció gramatical seria així només una mena de codi per a mantenir un ús cohesionat entre els parlants de les diferents varietats de la llengua, però innecessari per a expressar els significats: aquests estarien codificats en el lèxic, i la comunicació s'activaria amb processos de multimodalitat (gestualitat, proxèmica, recursos paralingüístics, veu i entonació, etc.). Quant al domini de la gramàtica, arribaria espontàniament, com passa amb els infants quan adquireixen la seva primera llengua.

S'hi afegia una altra observació inquietant i paradoxal. Es comprovava com hi havia persones que assolien un ús prou fluid i eficaç d'una nova llengua sense haver assistit a cap curs, només comunicant-se espontàniament en entorns socials en què es feia servir aquesta llengua, i moltes vegades superant folgadament altres persones que exhibien un prestigiós diploma de suficiència. Més sorprenent encara: aquestes persones havien assolit un domini gairebé complet de les regles bàsiques de la morfologia i de la sintaxi. Però, malgrat la seva fluïdesa, eficàcia comunicativa, riquesa lèxica i acceptable correcció gramatical general, presentaven deficiències molt concretes en determinats punts gramaticals, sense arribar tampoc a superar-les mai. En el cas de les llengües romàniques, aquests problemes solien girar al voltant dels temps verbals del passat (especialment, els seus valors aspectuals), del subjuntiu, de l'article determinat i, particularment en català, dels pronoms febles. Fenòmens, tots aquests, que, per altra banda, eren els esculls més forts per a aquells que assistien a classes: arribaven a poder parlar-ne i explicar-los amb força precisió, però els costava molt interioritzar-los per tal de fer-los servir en la comunicació real i espontània.

Per a explicar i explicar-se aquestes aparents paradoxes es va recórrer a les concepcions innatistes de la capacitat del llenguatge, de matriu chomskiana, extrapolant els trets dels processos d'adquisició de la primera llengua als de les llengües posteriors. Es va voler contraposar (Krashen 1981, Krashen \& Terrell 1984) el concepte d'adquisició d'una LA (produïda de forma espontània i natural, com es produeix l'adquisició de la L1) amb el del seu aprenentatge, dut a terme normalment en contextos d'escolarització, i alguns teòrics van arribar a afirmar que eren dos processos independents, sense cap mena d'interrelació (Martín Peris 2008, "Adquisición de segundas lenguas"). Altres de menys radicals van treballar amb la hipòtesi que entre els continguts "apresos" i els "adquirits", si no és que ambdós tipus s'emmagatzemaven junts a la ment, com a mínim hi havia nexes, i van investigar fins a quin punt l'ensenyament era efectiu en el desenvolupament de la competència dels aprenents i quins tipus de pràctiques, ho eren més, d'efectives.

Com a resultat d'aquest conjunt d'experiències per part dels docents i dels investigadors es van fer diverses propostes concretes per a abordar l'ensenyament de la gramàtica, independentment del mètode que es seguís en cada cas. Tothom estava d'acord que calia trobar una forma d'ensenyar gramàtica que no s'aturés en el coneixement explícit de les formes i les regles, sinó que efectivament incorporés aquest coneixement en una pràctica espontània de la comunicació duta a terme amb correcció gramatical. En aquest sentit, des dels anys 70 del segle XX van assolir gran predicament propostes com la d'i+1 de Stephen Krashen (1985), d'Input processing de Bill van Patten (1996), o de Focus on form de Michael Long (1983, 1991) i Sandra Fotos (1993).

És en el context d'aquesta discussió sobre el lloc de la gramàtica en l'ensenyament-aprenentatge de llengües que apareix la proposta de l'ensenyament basat en conceptes (EBC), en el marc de la teoria sociocultural de l'aprenentatge. Més que no sobre el tractament de la gramàtica en general, l'EBC es proposa la superació d'aquells esculls particulars d'una llengua per a 
cada aprenent o grup d'aprenents, ja que s'accepta com a evident que hi ha una gran quantitat de continguts gramaticals que tots assoleixen amb facilitat i de forma més o menys ràpida. Estaríem així, altre cop, en una tessitura semblant a la de la "prevenció i correcció de l'error"; ara, però, en un context molt diferent, això és, el d'un enfocament comunicatiu que fomenta l'aprenentatge mitjançant la pràctica de la comunicació, ara no només una pràctica interactiva sinó també i alhora reflexiva.

En el seu model, l'EBC recorre a les aportacions recents inspirades en la lingüística cognitiva (R. W. Langacker, 1987). Com és sabut, la lingüística cognitiva sosté que totes les formes lingüístiques (lèxiques, morfològiques i sintàctiques) són significatives, i que el seu significat "adopta la condició d'estructura conceptual, més o menys complexa, més o menys abstracta" (Castañeda Castro, 2004: 1). En les diferents opcions gramaticals que el parlant té a la seva disposició per a transmetre un mateix missatge, i que en altres corrents no són altra cosa que opcions formals desvinculades del significat, la lingüística cognitiva hi descobreix diferències de significat. Aquestes diferències deriven de la dimensió representacional dels signes lingüístics, que permet adoptar diferents configuracions d'una mateixa realitat; el parlant representa verbalment aquesta realitat amb una imatge que reflecteix la percepció que en té. En un altre lloc, Castañeda exposa els avantatges de l'aplicació d'aquesta teoria a l'ensenyament de LA (Castañeda Castro 2006: 34/26-27):

- Paral-lelisme amb principis generals de percepció i amb altres formes de representació (com ara la gràfica).

- Totes les estructures del llenguatge es consideren símbols, associacions entre significants i significats, representacions conceptuals naturals.

- Les funcions discursives i pragmàtiques es basen precisament en l'existència de representacions alternatives d'una mateixa situació objectiva.

- Les explicacions "representacionals" no necessàriament són excloents. Són integrables en descripcions pluridimensionals aplicables al criteri discrecional del docent.

- El treball de l'alumne amb exemples i exercicis pot ser sistemàticament significatiu quan la descripció de partida és significativa i intuïtivament assimilable.

D'aquesta forma, la lingüística cognitiva ha contribuït a destacar el paper important de la gramàtica en la creació de significats ${ }^{4}$. Això ha permès una reorientació o, si es vol, una interpretació correcta dels enfocaments comunicatius (atès que aquets enfocaments prioritzaven la capacitat de negociació del significat en la comunicació sobre la correcció en els aspectes formals) i una ampliació dels temes i continguts que cal fer explícits en l'ensenyament de llengües (aspecte i mode verbals, preposicions, articles definit i indefinit, ordre dels constituents de la frase, posició pre- o postnominal de l'adjectiu, etc.).

\section{La teoria sociocultural de l'aprenentatge i l'ensenyament de LA}

En els programes inspirats en l'enfocament comunicatiu, el debat sobre l'ensenyament-aprenentatge de la gramàtica s'havia decantat cap a la necessitat d'afavorir la interiorització de les formes lingüístiques. Així, es va establir una dicotomia entre les activitats dutes a terme en el si d'aquest ensenyament; unes serien d'atenció al significat i unes altres d'atenció a la forma. Les activitats d'atenció al significat es duien a terme en tasques en les quals abans que res calia assolir un objectiu comunicatiu, i cada alumne havia de fer servir els recursos i estratègies personals que tingués a mà. En les activitats d'atenció a la forma, els alumnes havien de reparar en aspectes gramaticals concrets que formaven part de l'actuació lingüística: la pròpia, la dels seus interlocutors i la dels textos que s'hi feien servir. És a dir, la programació i seqüència

4 Castañeda et al. 2014 i Llopis García et al. 2012 són dues aplicacions dels principis de la lingüística cognitiva a l'ensenyament del castellà com a LA. 
del contingut de l'aprenentatge no es feia a partir d'unitats del sistema formal, sinó d'unitats conceptuals, com va proposar inicialment D. A. Wilkins a Notional Syllabuses (1976). Això formava part de les últimes versions dels enfocaments comunicatius (ensenyament per tasques, ensenyament per projectes...) (Martín Peris 1992, 2001). Es confiava que una atenció prioritària al significat potenciaria, en els aprenents "escolars", els mecanismes (no prou coneguts i explicats) pels quals els aprenents "naturals" (els que no seguien cursos) interioritzaven la major part del component formal de la llengua, només parant atenció al significat; i que parant una atenció simultània al significat i a la forma en les pràctiques de l'aula se'ls ajudaria a superar les dificultats concretes de la gramàtica que suposaven aquells esculls tan forts.

Des de fa unes dècades la teoria sociocultural de l'aprenentatge - TSA - (Lantolf \& Poehner 2008, Esteve et al. 2013, Anton 2010, Negueruela 2013, Negueruela \& Lantolf 2006) exerceix una forta influència en alguns cercles de l'ensenyament de LA. Aquesta teoria s'inspira en la psicologia de Vigotski i els seus seguidors (Leontief, Luria, Galperin...), que es caracteritza bàsicament per concebre l'aprenentatge com un procés mediat socialment; és a dir, considera que el desenvolupament cognitiu de la persona procedeix sempre del món extern (social) al món intern (mental): l'autorregulació o l'activitat intramental no s'assoleix sense una fase prèvia d'heterorregulació o activitat intermental. I en el marc de la discussió sobre la manera d'afavorir la interiorització del component gramatical d'una LA (en el sentit més ampli d'aquest adjectiu), proposa un ensenyament basat en conceptes (EBC). Com afirma Negueruela (2013: 55), "los puntos gramaticales difíciles de aprender en una segunda lengua lo son por cuestiones fundamentalmente conceptuales y no tanto por cuestiones morfológicas o sintácticas".

\begin{abstract}
"[Vigotski] basa el seu pensament en la coneguda noció de Marx del treball com a activitat humana fonamental, que ens connecta amb el món material dels objectes concrets i les relacions humanes. Proposa Vigotski que l'activitat de la parla serveix per a mediar la nostra relació amb el món; segons ell, els humans per si mateixos tenen la capacitat no només de regular i transformar les circumstàncies en què viuen, sinó també la de regular els seus propis processos mentals, incloent-hi la memòria, l'atenció, la planificació, la percepció, l'aprenentatge i el desenvolupament. Cap altra forma de vida —argumenta - té aquesta capacitat. El que ens atorga aquest enorme poder sobre les nostres pròpies formes de vida és l'activitat socialment organitzada, mediada per la parla. Així, des de la perspectiva de Vigotski, comunicar-se suposa molt més que expressar els nostres pensaments: la comunicació és el procés mitjançant el qual es completa el pensament, tant si és de naturalesa social com privada" (Lantolf 2002: 2, traducció pròpia).
\end{abstract}

Assenyala també Lantolf (2006) que la diferència més gran entre la TSA i les teories precedents basades en supòsits adquisicionistes és que aquestes consideren l'aprenentatge d'una LA com el resultat d'un procés natural, el factor central del qual és l'individu, mentre que la TSA el considera com una tasca colllaborativa entre l'individu, altres persones i els artefactes culturals que tenen a l'abast.

L'EBC fa servir aquests artefactes de la TSA en la forma particular de gràfics i diagrames que representen visualment l'estructura i funcionament del concepte que es vol ensenyar, i del que en el següent apartat presentem una mostra apropiada per a l'ensenyament del català. Segons els autors que proposen aquest model, el problema de les anteriors aproximacions era el seu objecte d'aprenentatge, que concebien com a formes lingüístiques, quan del que es tracta és que els aprenents interioritzin els conceptes que aquestes formes han de vehicular. En la presentació d'aquests conceptes als alumnes es dona gran importància a la qualitat dels coneixements explícits que se'ls proporciona i es descarta la utilitat de les regles d'ús simplificades, que tradicionalment es feia servir com una mena de drecera.

Així doncs, aquesta nova proposta de la teoria sociocultural de l'aprenentatge aplicada a l'ensenyament de llengües es distingeix de gran part de les anteriors per dos trets: en primer lloc, es manté dins un enfocament comunicatiu, l'objectiu del qual és el desenvolupament de la 
competència comunicativa; en segon lloc, pren com a objecte d'aprenentatge un concepte de qualsevol dels components de la llengua en ús (discursiu, pragmàtic, sintàctic, etc.) i, en particular, del component gramatical (és a dir: no pas la forma, sinó el concepte).

Resumint, els postulats fonamentals de la TSA són aquests:

1. La relació de la ment humana amb el seu entorn no s'estableix de forma directa, sinó a través d'artefactes que han estat desenvolupats en el sí de la societat. Això vol dir que la ment actua per intermediació d'aquests artefactes: l'ordre alfabètic, el sistema de numeració, etc., en poden ser alguns exemples. En l'aprenentatge d'una LA són molts els artefactes que hi intervenen tradicionalment: en primer lloc, els diccionaris i glossaris, els manuals o llibres de text; també els esquemes gramaticals, les imatges que acompanyen algunes lliçons, etc. D'aquesta funció dels artefactes se'n diu la mediació del coneixement.

2. Tot aprenentatge humà - i no només el d'una llengua - es concep com la interiorització d'unes capacitats que s'han exercit inicialment en un entorn social i amb la col-laboració d'altres persones. Això és particularment visible en l'aprenentatge de la primera llengua: l'infant només és capaç de comunicar-se amb els adults que l'envolten gràcies al fet que aquests li proporcionen una mena de bastida, en la qual ell es recolza i arriba fer-se entendre. Això mateix succeeix quan una persona adulta, posem per exemple un immigrant, arriba a un nou medi social on es parla una llengua que no coneix: sense haver anat a classe a estudiar-la, es pot fer entendre perquè els seus interlocutors li proporcionen aquesta mena de bastida. A poc a poc, es van interioritzant els recursos i les estratègies de comunicació fins que la persona pot fer-los servir de forma autònoma, ja no li cal el bastiment.

3. Aquest fenomen va ser descrit per Vigotski (1934) amb la metàfora de la zona de desenvolupament proper (ZDP). I el suport que proporcionen els adults als infants va ser descrit precisament amb la de la bastida (scaffolding, en anglès) per un dels seus seguidors, J. Brunner (1960). La ZDP és aquell estadi del procés d'aprenentatge en el qual un aprenent pot fer una determinada cosa si disposa de bastida i que se supera quan ja la pot fer de forma autònoma. Posem per cas que una persona que acaba d'arribar a Catalunya fa poc temps té un accident i ha d'anar a l'hospital; ella sola no seria capaç de relatar — diguem que davant una gravadora - com es va produir l'accident, però amb la intervenció col.laboradora del personal sanitari pot arribar a donar-ne tots els detalls. Aquesta mediació en la producció d'un determinat discurs pot exercir-la un parlant més competent que la persona interessada; però també pot exercir-la un d'igual o de menys competent. És el que passa a l'aula, on entre dos o tres companys poden dur a terme una tasca que cadascun d'ells individualment no podria fer: tots plegats sabem més coses i som capaços de fer-ne més i millor que cadascun de nosaltres per separat. D'això en diem aprenentatge col-laboratiu, que la TSA explica amb les metàfores de la ZDP i de la bastida. El més important aquí és l'èmfasi en el caràcter social de tot aprenentatge: s'inicia en el món extern, des d'on passa a l'interior de la persona, i això gràcies a la mediació. Les habilitats mentals superiors - i el domini d'una LA n'és una- apareixen en primer lloc en interacció amb altres persones i amb l'ús d'artefactes culturals; només més endavant, quan han estat interioritzades, la persona pot exercir-les per si mateixa.

4. L'artefacte més poderós que ha desenvolupat la humanitat és el llenguatge: el llenguatge fa de mediador en la relació de la persona amb el altres humans, amb les seves accions i amb el seu món interior. No hi ha cap aprenentatge en el qual el llenguatge no intervingui d'una manera essencial: només cal pensar, per exemple, en com aprenem música, o matemàtiques, o balls de saló o un ofici; parlem amb els instructors, parlem amb els companys, parlem amb nosaltres mateixos. Sense aquestes converses, l'aprenentatge seria impossible. D'aquí la importància, no només de la pràctica oral de la llengua, sinó sobretot de la L1 en l'aprenentatge d'una LA: si alguns enfocaments tradicionals li barraven el pas a l'aula de LA, els postulats vigotskians parlen clarament de la necessitat d'introduir-la 
com a element mediador de l'aprenentatge. Les funcions de la L1 en l'aprenentatge de la LA han estat estudiades i se'n poden distingir, com a mínim, les següents:

1. Resoldre qüestions organitzatives de l'aula (assignació de tasques i deures, informacions sobre exàmens, etc.).

2. Servir de metallenguatge per a explicar i aclarir qüestions lingüístiques (entre docent i alumnes tots plegats).

3. Facilitar la gestió de les tasques col-lectives entre els alumnes.

4. Formular expressions espontànies, de contingut sobretot emocional però no tan sols.

5. Servir de suport a llenguatge interior de cada alumne, habitual en tota realització de tasques complexes, en qualsevol esfera de les accions humanes.

En aquest sentit, l'ús de la L1 a l'aula de la LA no és quelcom que neixi de la manca de domini que els aprenents en tenen ${ }^{5}$. La seva importància rau en el fet que, com ja s'ha dit, en la teoria de Vigotski el llenguatge és l'artefacte simbòlic més important de la persona per a regular la seva activitat cognitiva, per tant, el que millor farà la funció mediadora de qualsevol aprenentatge, inclòs el d'una LA:

"El llenguatge ens proporciona els mitjans per a pensar sobre el llenguatge. Negar això equival a limitar la nostra capacitar semiòtica. La nostra L1 ens ofereix una oportunitat de representar-nos conscientment els significats d'una LA. Negar-nos a nosaltres mateixos aquesta oportunitat semiòtica és negar-nos les possibilitats que la llengua ens ofereix" (Holme, citat a Lantolf \& Thorne 2006: 295).

\section{L'ensenyament basat en conceptes}

La idea de Lantolf que aprendre una nova llengua no és dominar un conjunt de formes lèxiques i gramaticals noves sinó desenvolupar nous conceptes casa perfectament amb la tesi de Vigotski que el concepte és la unitat bàsica de l'aprenentatge. L'ensenyament basat en conceptes pretén que l'aprenent assoleixi una comprensió més profunda de les formes gramaticals que li cal aprendre, que entengui i interioritzi els conceptes que rauen a la base d'aquestes formes i les seves funcions. Un exemple molt típic del català és el de la referència anafòrica. Per tal que un aprenent de català com a LA aprengui bé el sistema dels pronoms febles i les seves funcions, cal que comprengui bé els conceptes de dixi i anàfora.

Segons Negueruela (2013), els trets fonamentals d'aquest enfocament són els següents:

1. El concepte com a unitat mínima per a l'ensenyament de la gramàtica. Cal oferir als aprenents explicacions conceptuals sistemàtiques i completes, enlloc de regles gramaticals d'ús simplificades.

2. La importància dels models didàctics. No es poden internalitzar els conceptes a través de llargues explicacions teòriques. Amb una varietat de gràfics, models i esquemes, capaços de captar l'essència del concepte que s'està estudiant, l'aprenent haurà de crear els seus models pràctics.

3. L'autorreflexió verbalitzada, en forma oral o escrita: l'aprenent explica - a ell mateix o a d'altres - la comprensió que ha assolit del fenomen i la forma com es fa operatiu en la pràctica.

Per a dur a terme aquest EBC cal escollir un concepte de la LA i constituir-lo en una unitat d'aprenentatge. Mitjançant l'ús de figures, esquemes i diagrames que recullin la composició abstracta del concepte, es condueix els aprenents al reconeixement de la semàntica i la pragmàtica del concepte, i a relacionar-lo en determinades formes gramaticals. D'aquesta forma, 
s'espera accelerar l'aprenentatge d'aquestes formes, sense esperar que l'aprenent hagi assolit una competència comunicativa i lingüística avançada.

És important destacar que en diferents llengües hi ha diferents recursos per a la creació del significat, però que tot pot ser expressat en totes les llengües. D'aquí la importància de l'enfocament conceptual: la referència anafòrica existeix en català i en castellà; en català es farà servir un pronom en on el castellà hi haurà una el-lipsi. El que cal que entengui l'aprenent és el concepte de referència anafòrica, $\mathrm{i}$ això li permetrà interpretar $-\mathrm{i}$, donat el cas, produir- el recurs anafòric adequat en cada llengua.

De la mateixa manera que en un ensenyament gramatical basat en les formes no cal que els aprenents facin servir els termes lingüístics de subjecte, predicat, pronom, article, etc., per a arribar a produir correctament un enunciat com ara $\mathbf{E l}$ que passi demà ho sabràs demà passat, en el cas de l'EBC no cal que expliquem tècnicament què és l'anàfora; n'hi ha prou que els aprenents entenguin què és i vegin com opera.

El aprendizaje de estos conceptos no es una cuestión de presentar explicaciones perfectas o de una práctica comunicativa implícita. Desde un punto de vista pedagógico, la clave está en usar estos conceptos como herramientas comunicativas reales (Negueruela 2013: 66).

L'EBC consta d'un seguit de fases, tal com les va proposar inicialment Y. Galperin (citat a Lantolf \& Thorne 2006):

- Fase de motivació, en la qual s'introdueix els alumnes en el coneixement teòric que es vol desenvolupar i se'ls presenta l'esquema general de la seqüència didàctica; es presenta el material d'aprenentatge com un tot integrat i ple de sentit: objectius, contingut, eines de mediació i fases de la seqüència.

- Fase de materialització del coneixement conceptual, mitjançant una esquematització gràfica d'aquest coneixement, que ajudarà els aprenents com a base per a regular les seves accions. D'aquí el nom que li dona Galperin: SCOBA (Scheme of a Compete Orienting Basis of an Action).

- Segueixen altres fases en les quals els aprenents fan servir els conceptes amb els recursos gramaticals observats i entesos amb l'ajuda de l'SCOBA, i altres successives en les quals verbalitzen la seva comprensió dels conceptes i de la forma com ha progressat el seu aprenentatge de la llengua.

En la mostra que presentem a continuació ens centrarem només en la segona fase, amb un SCOBA que hem elaborat expressament.

\section{Exemple d'EBC aplicat al català-LA}

L'exemple que oferim a continuació és una prova d'aplicació de l'ensenyament basat en conceptes al català com a llengua addicional. Cal avisar, d'entrada, que es tracta d'una temptativa que no ha estat experimentada a l'aula. Més que no per a la seva utilització directa en una classe, l'hem preparada com a exemplificació per al professorat, que, si la vol fer servir, podrà adaptar-la a les condicions concretes del seu context d'ensenyament.

Hem triat un tema molt particular de la gramàtica, que presenta dificultats a molts grups d'aprenents: els mecanismes de tematització i rematització dels enunciats i les referències anafòriques que se'n deriven. I està pensada per a aprenents d'un nivell inicial.

Calia fer una selecció de les formes i estructures gramaticals afectades per aquest fenomen, atès que la diversitat de combinacions que es poden donar entre elles faria massa complex explicar el fenomen en la seva totalitat. Així, hem deixat fora el complement nominal, l'atribut, l'adjunt, el predicatiu i, lògicament, els casos de lexicalització del pronom. Un cop entès 
el fenomen en algunes de les seves realitzacions, no hauria de ser difícil extrapolar aquesta comprensió a la resta; i, per descomptat, el professorat pot anar proporcionant nous esquemes com el que presentem, o bé ampliant-lo. De la mateixa manera, alguns dels complements que hem incorporat a l'esquema general (en particular, el complement indirecte) els hem deixat només apuntats.

La seqüència que proposem s'emmarca en la realització d'una tasca d'aprenentatge comunicatiu; però d'aquesta tasca només n'enunciem el tema i el resultat; no n'expliquem l'estructura amb els seus continguts i procediments, per tal d'evitar una possible dispersió i centrar-nos en una mostra de l'EBC.

Per a poder fer operatiu el coneixement dels procediments de l'anàfora i de l'ús dels pronoms febles és condició indispensable estar familiaritzat, ni que sigui intuïtivament o inconscientment, amb la semàntica del verb de la frase: quants actants o arguments té, i si el component sintàctic que els representa és de presència obligada a la frase. Per tal de facilitar l'adquisició d'aquest coneixement hem inclòs uns exercicis previs.

L'exercici núm. 1 pretén cridar l'atenció dels alumnes sobre les possibilitats d'alterar l'ordre canònic de la frase (subjecte-verb-complements) i les conseqüències de tipus sintàctic i comunicatiu que se'n deriven. Comptem amb el més que probable coneixement, per part dels alumnes, del vocabulari bàsic de la sintaxi, tot i que no resulta imprescindible dominar-lo per seguir l'activitat.

A continuació d'aquest exercici es presenta l'objecte d'aprenentatge, la comprensió del qual resultarà més accessible gràcies a l'activitat que acabem de dur a terme. Renunciem expressament a la terminologia de les funcions informatives (tema, rema...) i a la de les semàntiques (estructura argumental, agent, pacient, instrument...). En el seu lloc, en glossem el concepte quan ens cal fer-lo servir.

L'exercici núm. 2 ha de servir per a entendre el fenomen de l'estructura argumental del verb, juntament amb el fet que alguns dels arguments han d'estar explicitats a l'enunciat, mentre que altres poden ser el-líptics. Aquest fenomen s'explica de forma més detallada a l'apartat que ve a continuació de l'exercici, "IV.- L'estructura de la frase". S'hi fa servir la terminologia de la sintaxi, previsiblement més familiar als alumnes que no la de l'estructura argumental; cal assenyalar, però, que els conceptes respectius no es corresponen biunívocament; poden coincidir en alguns casos en una mateixa unitat lingüística (el subjecte del verb i l'agent: "els atletes salten a la pista”), però no sempre (subjecte i experimentador "el porter té una lesió muscular").

És important també tenir present que es treballa amb frases i no amb verbs aillats. Hi ha verbs amb un únic argument de tipus agentiu ("No corris, que no tenim pressa"), que poden ser utilitzats en frases amb dos arguments: "Enguany correré la marató".

És evident que la llengua en ús sempre es presenta en unitats textuals, supraoracionals i suprafrasals. En la mostra que presentem, la dimensió textual de la llengua i el corresponent treball comunicatiu i cognitius dels aprenents venen assegurats pel fet que l'exercici s'emmarca en el context d'una activitat que segueix el model de l'ensenyament per tasques, i això comporta automàticament l'ús de textos com a base per al treball d'ensenyar i d'aprendre. La cita de Negueruela (2013: 66) uns paràgrafs més amunt ("usar estos conceptos como herramientas comunicativas reales") implica igualment la necessitat de l'ús de textos en una comunicació real.

També cal remarcar que presentem el recurs de l'anàfora en el context limitat de la frase (autoanàfora), tot i que es dona també amb un referent explicitat en una altra frase, del mateix interlocutor o de l'altre (heteroanàfora). I, encara més, que, sobretot en la llengua oral i col-loquial, pot estar present en la ment dels dos interlocutors per experiències compartides, sense necessitat que hagi estat explicitat: "Escolta, que ja els tenim aquí" (amb referència a unes entitats que no han estat esmentades en aquesta frase ni en les anteriors). 
L'exercici núm. 3 té com a finalitat acabar d'assimilar els conceptes treballats fins al moment. Es tracta de veure com hi ha verbs que només requeriran un argument (esternudar), altres que podran formar frases amb un o dos arguments (dormir / dormir la migdiada), verbs que poden deixar el-líptic un argument amb preposició (arribar - a un lloc), etc.

L'exercici núm. 4, finalment, presenta un dels artefactes típics de l'EBC, un diagrama per a guiar l'operació mental, cognitiva i comunicativa, de l'aprenent. Com en la resta de tot l'article, però aquí de manera especial, en la mesura del possible es prescindeix de la terminologia científica i en el seu lloc es glossen els termes que s'haurien emprat. Cal fer algunes precisions al respecte:

- En parlar de circumstàncies de l'esdeveniment ens referim pròpiament als complements circumstancials, exclosos, però, els que representen arguments del verb amb preposició (parlar d'alguna cosa). Com a circumstàncies espacials s'hi inclou l'activitat; una activitat no és una circumstància espacial, però els parlants la perceben com a tal quan s'hi refe-

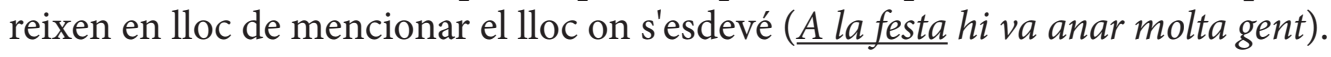

- Per elements participants entenem pròpiament els arguments; com que aquests es manifesten en components sintàctics, ens hi referim utilitzant aquests termes: subjecte, complement directe, complement indirecte, complement preposicional.

Finalment, cal recordar que no tot el que diem complement circumstancial són circumstàncies externes a l'esdeveniment; hi ha els complements argumentals com tema amb preposició, molts d'ells amb verbs reflexius: penedir-se de, avergonyir-se de, etc. Caldrà, doncs, considerar-los com a elements participants en l'esdeveniment.

\section{Materials i instruccions de la seqüència}

\section{Tasca comunicativa en què s'emmarquen els exercicis}

"En grups de tres hem de distribuir les tasques de la compra d'ingredients per a una festa que volem fer."

\section{Exercici 1}

Llegiu les frases A-E. Responeu les preguntes que hi ha a continuació i després digueu quin(s) fenòmens penseu que estudiarem en aquesta unitat didàctica.
A. El meu avi llegeix el diari cada dia al metro.
B. El diari, el meu avi el llegeix cada dia al metro.
C. Al metro, el meu avi hi llegeix cada dia el diari.
D. Cada dia, el meu avi llegeix el diari al metro.
E. Cada dia, al metro, el meu avi hi llegeix el diari.

Preguntes:

1. Hi ha una frase que es distingeix de totes les altres per un tret. Quina és i quin és aquest tret? (Té a veure amb l'ordre sintàctic.)

2. La resta de frases tenen també un tret en comú. Quin és? Per què els parlants recorren a aquest tret en el seu discurs oral o escrit?

3. En què coincideixen les frases $\mathrm{F}$ i $\mathrm{G}$ amb les anteriors? En què difereixen?

F. Llegir el diari, el meu avi ho fa cada dia al metro.

G. De diaris el meu avi en llegeix cada dia dos o tres al metro.

4. Hi ha tres frases en el grup A-E que, al seu torn, tenen un component que no és a les altres dues. Subratlleu-lo. Trobeu l'equivalent a les frases F i G. 
5. Comproveu com es dirien aquestes frases en la vostra llengua. Potser hi feu servir pronoms, igual que en català; o potser no n'hi poseu, però el contingut queda sobreentès. Teniu els equivalents de les formes en i hi en la vostra llengua o en altres llengües que coneixeu?

\section{Objecte d'aprenentatge}

El fenomen que estudiarem avui consisteix a posar a l'inici de la frase algun dels complements del verb, alterant així l'ordre sintàctic neutre (subjecte-verb-complements).

D'aquesta forma indiquem als nostres interlocutors què és allò sobre el que volem dir alguna cosa. És el que passa amb les frases B-E de l'exercici 1.

També és freqüent, en llengua oral, portar aquell element no a l'inici de la frase, sinó al final de tot, al darrere d'una petita pausa:

H. El meu avi hi llegeix cada dia el diari, al metro.

I. El meu avi en llegeix cada dia dos o tres al metro, de diaris.

Aquest canvi d'ordre sintàctic sol tenir conseqüències diferents en cada llengua. Potser podeu comprovar-ho en les diverses llengües que coneixeu individualment o entre els membres del grup.

En català, aquestes conseqüències tenen a veure amb la inclusió dels pronoms personals febles. Ens fixarem particularment en les formes en, hi, ho.

Per a entendre bé com funcionen aquests mecanismes és d'una gran ajuda conèixer l'estructura de la frase i com es relacionen amb el verb els diferents elements que la formen. Dedicarem a això l'exercici següent.

\section{Exercici 2}

Mireu de suprimir algun dels elements subratllats (sense substituir-lo per cap altre) en aquestes frases i digueu si les frases resultants són acceptables o prou informatives, o si no ho són.

$\underline{\text { Ahir vam visitar la Sagrada Família amb un grup d'amics }}$

Demà comencen a Barcelona les festes de la Mercè

$\underline{\text { L'últim dia ens entregaran un certificat d'assistència }}$

Tothom volia anar al concert dels Amics de les Arts

I ara mireu d'afegir algun element (l'1, el 2, o tots dos junts) a les tres frases incompletes (poseu-hi les preposicions que calguin):

1. Aquesta litografia d'un Picasso

2. La seva filla

a. Els nostres veïns han regalat

b. Jo sempre havia admirat

3. De cap manera m'acomiadaré

\section{L'estructura de la frase}

Normalment, amb una frase ens referim a un esdeveniment o situació del món en què vivim, o també d'un món imaginari. En qualsevol d'aquests esdeveniments hi ha els components següents:

- Dues circumstàncies que hi són sempre presents: un moment del temps i en un lloc de l'espai. És el que passa en les frases A-E: “cada dia" i "al metro". No sempre la frase diu quins són aquests moments i aquests llocs, però sempre hi són en realitat. Les coses no succeeixen en el no res, fora d'un temps i d'un espai. 
- Altres possibles circumstàncies: si l'avi del metro llegeix el diari amb ulleres o sense, si va sol o acompanyat, si dret o assegut, si començant pels esports, l'economia o l'editorial... no acabaríem mai d'enumerar les possibles circumstàncies.

- Avui retindrem la circumstància de LLOC, que és una de les més importants per al funcionament dels pronoms $h i$ i en. Les altres, les deixarem per a més endavant.

- La situació o l'esdeveniment a què es refereix la frase sol estar referida per un verb (llegir, menjar, viatjar, dormir...). I en allò que expressa aquest verb poden formar-se tres tipus de frases:

I. Frases on només intervé una entitat (una persona -o un grup de persones-, un animal, un objecte, una institució, una idea...). Són frases formades al voltant de verbs com nàixer, caure, riure, créixer...

II. Frases on intervenen dues entitats, formades al voltant de verbs com fabricar, mirar, estimar...

- En català, les dues entitats es relacionen amb el verb sense cap preposició: estimar els amics, mirar la tele. Són les frases amb complement directe (si coneixeu aquest terme, perfecte; si no el coneixeu, tant se val, el que importa és entendre la idea).

- Hi ha altres verbs que no tenen complement directe, però necessiten una segona entitat, que es relaciona amb el verb amb una preposició: parlar DE (alguna persona o alguna cosa), acostumar-se A (tal cosa), sortir DE tal lloc, arribar A tal lloc, penedir-se DE tal cosa, oblidar-se DE tal cosa...

III. Frases on intervenen tres entitats: la segona entitat (complement directe) passa entre les altres dues (el subjecte i el complement indirecte): donar (tal cosa a tal persona), preguntar, dir, explicar, exigir, perdonar...

IV. De fet, hi ha un altre tipus de frases, només amb el verb i sense cap entitat: ploure, nevar, tronar... Aquestes, als nostres efectes, no ens interessen.

L'ús dels pronoms (el/els, la/les, en, hi) ve determinat per quin d'aquests elements volem marcar com a tema del què parlem:

El diari el meu avi el llegeix cada dia al metro.

Al metro el meu avi hi llegeix cada dia el diari.

Cada dia, el meu avi $\emptyset$ llegeix el diari al metro.

\section{Exercici 3}

Formeu frases amb els verbs següents i després classifiqueu-les en un dels grups anteriors (I, II, III):

arribar, entregar, esternudar, retallar, començar, anar, acomiadar-se, visitar, dormir, plorar

\section{Exercici 4}

En grups de tres hem de distribuir les tasques de la compra d'ingredients per a una festa que volem fer. A la fi, escriurem en un full aquesta distribució.

El resultat esperat són frases com les següents:

La Montse i en Carles compraran el pastís.

El plats i els gots de paper els comprarà en Jaume.

De cava no en comprarem, és molt car.

Per a decidir com són les frases que escriurem i saber quins pronoms febles hi posarem, seguiu aquest diagrama: 


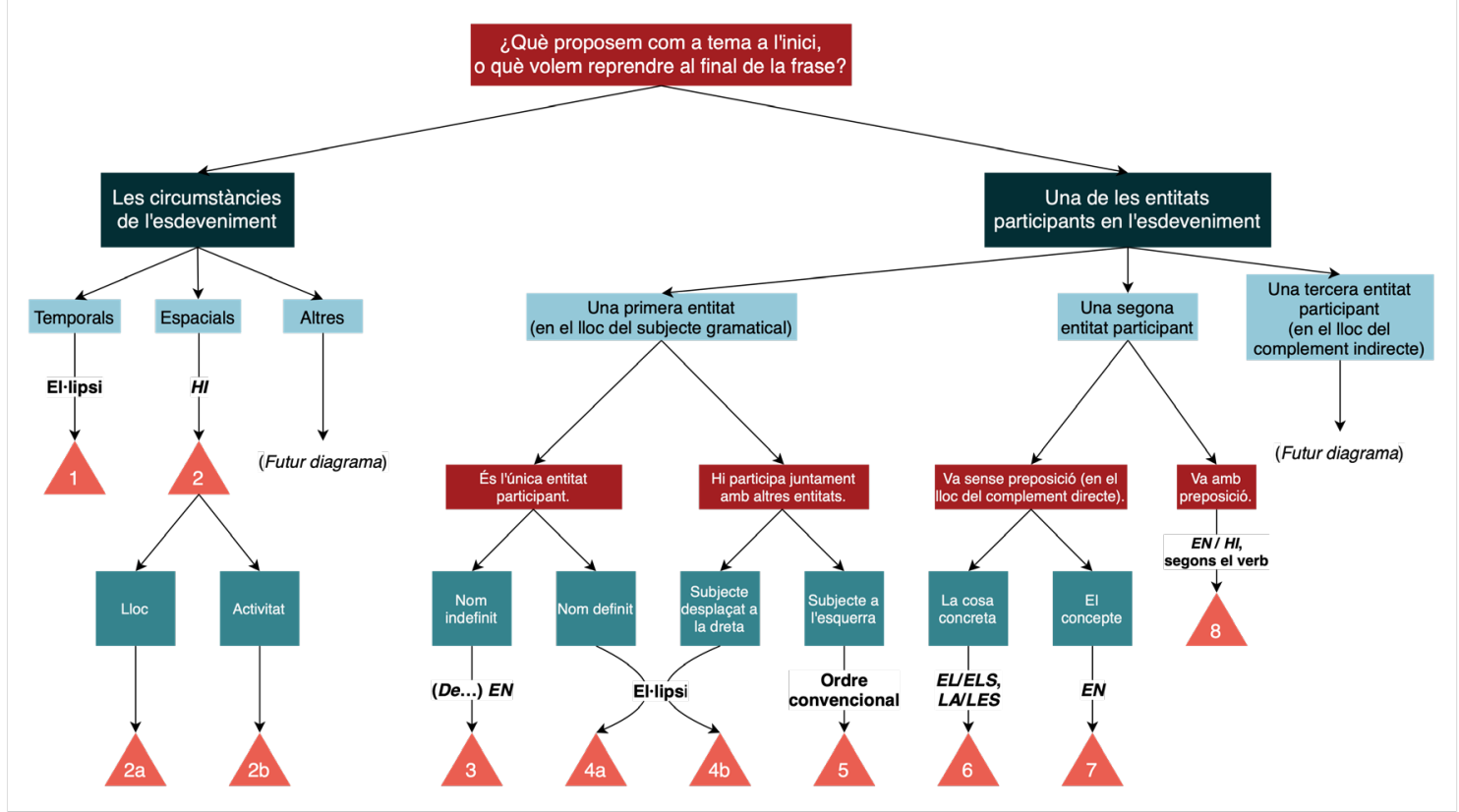

1 (El·lipsi)

Ordre canònic: Els seus amics cantaran una cançó abans dels regals.

Desplaçament: $\quad$ Abans dels regals, els seus amics $\emptyset$ cantaran una cançó. Els seus amics $\emptyset$ cantaran una cançó, abans dels regals.

$2(\mathrm{HI})$

2a

Posarem el pastís a aquesta taula del mig.

A aquesta taula del mig hi posarem el pastís.

Hi posarem el pastís, a aquesta taula del mig.

2b

Els seus amics cantaran una cançó a la festa.

A la festa, els seus amics hi cantaran una cançó.

Els seus amics hi cantaran una cançó, a la festa.

3 ((De ...) EN )

Ahir en va arribar un, de pastís.

De pastissos, en van arribar dos ahir.

\section{4 (El-lipsi )}

$4 a$

- ¿I el pastís?

- Encara no Ø ha arribat.

Encara no $\emptyset$ ha arribat, el pastís

- ¿I les cadires?

- Encara no Ø han arribat.

Encara no $\emptyset$ han arribat, les cadires.

$4 b$

$\emptyset$ Portaran les begudes, el Jaume i l'Elisa.

$\emptyset$ S'ocuparan de les begudes, el Jaume i l'Elisa. 
5 Si el subjecte va a l'esquerra, ja està tematizat, és l'ordre convencional

El Jaume i l'Elisa portaran les begudes.

El Jaume i l'Elisa s'ocuparan de les begudes.

6 (EL/ELS, LA/LES)

El pastís el faré jo.

Tu encomanaràs el pastís i jo l'aniré a buscar.

El cava el portaré jo.

Les cadires les portaré jo.

Vosaltres posareu les cadires i nosaltres les enretirarem.

Un pastís el faré jo; l'altre, tu.

Unes quantes cadires les podria portar jo.

7 (EN)

De cava en portaré jo.

De pastís no en tindrem / No en tindrem, de pastís.

De cadires no cal que en portis més que dues.

8 (EN / HI)

De les cadires me n'ocupo jo.

Me n'ocupo jo, de les cadires.

Amb la Maria hi parlaré jo, perquè porti les cadires.

Hi parlaré jo, amb la Maria, perquè porti les cadires.

\section{Conclusió}

En aquest article hem presentat un possible model d'aplicació de l'ensenyament basat en conceptes, derivat de la teoria sociocultural de l'aprenentatge, a l'ensenyament del català com a llengua addicional. El suport científic d'aquest enfocament, les seves bases conceptuals i l'experimentació i validació metodològiques de la seva aplicació estan recollides en la bibliografia que aportem, de manera especial a Negueruela 2010 i 2013, i Negueruela i Lantolf 2006a; aquí ens he limitat a explorar-ne les possibilitats en un cas concret de l'ensenyament del català. Hem obviat una presentació i discussió més detallades del desenvolupament de les tasques a l'aula, per tal de poder centrar-nos en allò més específic de l'EBC; per a un tractament més detallat de l'ensenyament per tasques, en el qual inserim la nostra proposta d'EBC, remetem als nostres treballs Bach, López-Ferrero i Martín Peris 2019, i Martín Peris 1992, 2001, 2010 i 2018.

Cal declarar, doncs, que la nostra proposta és temptativa, no ha estat experimentada a l'aula. Per tal d'adoptar el model de l'EBC caldrà provar a l'aula aquesta proposta que fem aquí, i experimentar-ne d'altres, centrades en altres conceptes. L'ensenyament de la gramàtica, com hem recollit en la introducció de l'article, ha estat objecte de molts debats i de moltes propostes, i cal saber fins a quin punt aquestes són exitoses. Hi ha hagut casos de propostes amb una gran difusió, que al poc temps han estat abandonades pels mateixos que les havien impulsades.

La nostra opció ha estat triar un concepte (o més aviat, un conjunt de conceptes) propis de la lingüística textual; però ha quedat ben patent l'estreta implicació mútua que hi ha entre els conceptes de la gramàtica textual i les unitats de la morfologia i la sintaxi; no de forma tan explícita, però també prou clara, s'ha pogut intuir la relació entre tots aquells conceptes i les formes amb la prosòdia. 
De fet, és poc menys que impossible abordar el tractament d'uns conceptes d'un determinat nivell de la descripció de la llengua sense considerar fenòmens d'altres nivells de la llengua. Tal com proposen Bach, López-Ferrero i Martín Peris (2019), entre els diferents nivells de descripció de la llengua hi ha una contínua interrelació:

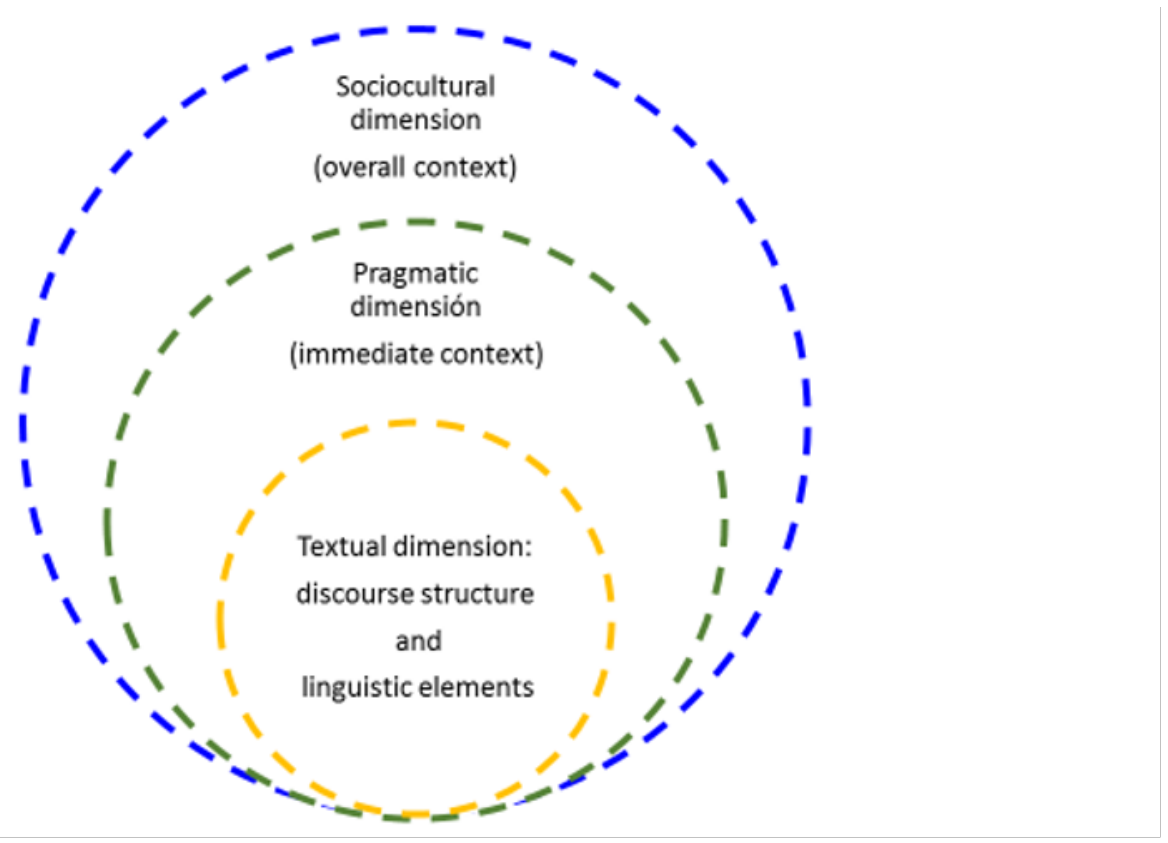

Així doncs, són molts i molt variats els conceptes que poden constituir l'objecte d'aprenentatge d'una activitat didàctica, i es poden triar de qualsevol dels nivells de descripció de la llengua representats en aquest esquema. És decisió del docent i el grup d'aprenents escollir quins conceptes es treballaran a l'aula. No tots presenten el mateix grau de dificultat o d'opacitat per a tots els aprenents, considerats aquests de forma individual o grupal. Els programes oberts a la intervenció dels participants fa temps que es van introduir en l'ensenyament de llengües ${ }^{6}$; la proposta de configurar així el programa és vàlida també per a l'EBC.

\section{Bibliografia}

Anton, M. (2010). Aportaciones de la teoría sociocultural al estudio de la adquisición del español como segunda lengua. RESLA 23, 9-30.

Bach, C., López-Ferrero, C. \& Martín Peris, E. (2019) Learners' discourse needs in everyday-life written genres. Working paper. https://www.upf.edu/web/ecodal/working-papers

Bruner, J.S. (1960). El proceso mental en el aprendizaje. Narcea (1978)

Castañeda Castro, A. (2004). Potencial pedagógico de la Gramática Cognitiva. Pautas para la elaboración de una gramática pedagógica de español/LE, RedELE (Revista electrónica de didáctica del español lengua extranjera). Ministerio de Educación y Ciencia. Marzo, (N. ${ }^{\circ} 0$ ) $<$ www.sgci.mec.es/redele/index.html>

Castañeda Castro, A. (2006). Perspectiva en las representaciones gramaticales. Aportaciones dela Gramática Cognitiva a la enseñanza de español LE. Boletín ASELE, 34, 11-28.

Castañeda Castro, A. (coord.) et al. (2014). Enseñanza de gramática avanzada de ELE: criterios y recursos. SGEL.

Ellis, R. (1990). Instructed Second Language Acquisition. Basil Blackwell. 
Esteve Ruescas, O. \& Martín Peris, E. (eds.) (2013). Cuestiones de autonomía en el aula de lenguas extranjeras. Horsori.

Fotos, S. (1993): “Consciousness and Noticing through Focus on Form: Grammar Task Performance versus Formal Instruction”. Applied Linguistics, 14/4.

Krashen S. \& T. Terrell (1984). The Natural Method: Language Acquisiton in the Classroom. Pergamon Press.

Krashen, S. (1981). Second Language Acquisition and Second Language Learning. Pergamon Press.

Krashen, S. D. (1985). The Input Hypothesis: Issues and Implications. Nueva York: Longman.

Kumaravadivelu, B. (1994). The Postmethod Condition: (E)merging Strategies for Second/ Foreign Language Teaching. TESOL Quarterly, 28/1, 27-49.

Kumaravadivelu, B. (2006). Understanding Language Teaching: From Method to Postmethod. Lawrence Erlbaum Associates.

Lacorte, M. (2013). Planteamientos ecológicos para la metodología del español como L2, Miríada Hispánica 6: 17-32

Langacker, W.R. (1987) Foundations of Cognitive Grammar. Stanford University Press.

Lantolf, J. P. (2002). El aprendizaje de una segunda lengua como comunicación una perspectiva sociocultural, La lengua como vehículo cultural interdisciplinar. Instituto Superior de Formación del Profesorado, MECD, (Colección «Aulas de verano»).

Lantolf, J. P. ed. (2000). Sociocultural Theory and Second Language Learning. Oxford University Press.

Lantolf, J. \& Poehner, M. (ed.) (2008): Sociocultural Theory and the Teaching of Second Languages. Equinox.

Lantolf, J.P \& Thorne, S. (2006). Sociocultural Theory and the Genesis of Second Language Development. Oxford: Oxford University Press.

Llopis-García, R., Real Espinosa, J.M. \& Ruiz Campillo J.P. (2012). Qué gramática enseñar, qué gramática aprender. Edinumen.

Long, M. H. (1983): Does second language instruction make a difference? A review of research. TESOL Quarterly 17, 359-382.

Long, M. (1991). Focus on form: A design feature in language teaching methodology. A de Bot, K., Ginsberg, R., Kramsch, C. (Eds.), Foreign language research in cross-cultural perspective. John Benjamins.

Martín Peris, E. (1992). L'ensenyament d'idiomes mitjançant tasques comunicatives. Com ensenyar català a adults, 21, 4-11.

Martín Peris, E. (2001). Què vol dir treballar a classe amb tasques comunicatives? Llengua i Ús (I), 55-66.

Martín Peris, E. (dir.) (2008). Diccionario de términos clave de ELE, Madrid: SGEL. https://cvc.cervantes.es/Ensenanza/biblioteca_ele/diccio_ele/default.htm

Martín Peris, E. (2010). ¿A qué nos referimos cuando hablamos de 'usar la lengua para aprenderla'? Bellaterra Journal of Teaching \& Learning Language \& Literature, 3, 1-17 http://ojs.uab.cat/index.php/jtl3/issue/view/18

Martín Peris, E. (2019). Pràctiques discursives situades: pràctiques comunicatives genuïnes. ARTICLES: Revista de didàctica de la llengua i de la literatura 78, 7-13. 
Negueruela, E. \& Lantolf, J. P. (2006a). Concept-based instruction and the acquisition of L2 Spanish. The Art of Teaching Spanish. Second Language Acquisition from Research to Praxis. Eds. R. Salaberry y B. Lafford. Georgetown University Press.

Negueruela, E. \& J. P. Lantolf (2006b). A concept-based approach to teaching Spanish grammar. Spanish second language acquisition: State of the art, ed. R. Salaberry \& B. Lafford, Georgetown University Press.

Negueruela-Azarola, E. (2010). Metáforas de la mente y enseñanza de idiomas: Principios básicos para un enfoque conceptual basado en la teoría sociocultural de la mente humana. Hispanismo y Lingüística, ed. Joaquín Sueiro-Justel et al. Axac. 27-48.

Negueruela-Azarola, E. (2013). Comunicación y pensamiento verbal en la enseñanza de la gramática. Un enfoque conceptual. Miríada Hispánica, 6, 53-70.

Prabhu, N. (1990). There is No Best Method - Why? TESOL Quarterly, 24/2, 161-176.

Richards, J.C. \& Rodgers, J. P. (1986). Approaches and Methods in Language Teaching. Cambridge University Press.

VanPatten, B. (1996). Input processing and grammar instruction in second language acquisition. Ablex.

Vigotski, L.S. (1934). Pensamiento y lenguaje. Pléyas (1977)

Wilkins, D. A. (1976): Notional Syllabuses. Oxford University Press. 
